\title{
Association Between Sources of Knowledge on Human Sexual Behaviour and Marital Satisfaction among Married People in Meru County
}

\author{
Agnes Karambu Maigallo \\ Department of Social Sciences, Chuka University \\ P.O. Box 109, 60400 Chuka, Kenya \\ Tel: +254721925558 E-mail: Maigallokarambu@gmail.com \\ Dr. Beatrice Mwarania Mburugu \\ Department of Education, Chuka University \\ P.O. Box 109, 60400 Chuka, Kenya \\ Tel: +254721428952 E-mail: bmburugu@yahoo.com \\ Prof. Adiel Magana \\ Department of Biological Sciences, Chuka University \\ PO Box 109, 60400 Chuka, Kenya \\ Tel: +254723147273 E-mail: adielmagana@yahoo.com
}

\begin{abstract}
1.1 Abstract
This study examines the sources of knowledge on sexual behaviour among married. Risky sexual behaviour is a problem that leads to dissatisfaction in many marriages in the world. Most conflicts in marriages are as a result of risky sexual behaviour. Sources of knowledge on sexual behaviour are instrumental in how a person manages their sexuality in marriage. How married persons manage affects satisfaction in marriage. There is a decline in marital satisfaction in Meru County as manifested by increase in marital violence, divorces and court cases related to custody and maintenance of children. Knowledge of sexual behaviour is a major contributor to marital satisfaction yet the association between sources of knowledge on sexual behaviour and marital satisfaction in Meru County had not been clearly established. This study intended fill the gap by establishing, the sources of knowledge on sexual behaviour and marital satisfaction in Meru County. The study adopted a causal-comparative research methodology. The target population of the study is 474,263 married people in Meru County from whom a sample of 384 respondents was drawn using multi-stage sampling. Data was collected from married people using questionnaires and Focus Group Discussions. Interview schedules were used to collect data from sexuality educators and marriage counsellors. Data obtained was analysed with the help of Statistical Package for Social Science for both descriptive and inferential statistics. A weak positive correlation which was not significant was demonstrated when sources of knowledge on sexual behaviour were correlated with marital satisfaction $\left(r_{s}=0.050\right.$, $p=0.393$ ).
\end{abstract}

Key words: Marital satisfaction, sexual behaviour, Intimacy, passion, commitment

DOI: $10.7176 / \mathrm{DCS} / 9-10-10$

Publication date:October $31^{\text {st }} 2019$

\subsection{Introduction}

Married individuals who have average to high levels of marital quality and harmony are more satisfied in their lives than their unmarried counterparts (Williams, 2003). According to Bradbury, Fincham, and Beach, (2000), marital satisfaction is largely influenced by how a man and woman in marriage understands, acknowledges and accepts their sexuality and that of their spouse The understanding, the acknowledgement and acceptance of sexual identity are determined to a great extent by the sexuality education received by a person (Gordon, 2007). According to Gordon, (2007), if sexuality education is taught appropriately, it can also help young people develop communication skills, as well as enhance their self-esteem and capacities in making decisions which are important in enhancing intimacy, passion and commitment in marriages

Sexuality Education refers to a comprehensive curriculum of instructions addressing not only the sexual anatomy and physiology but also reproduction, contraception, sexually transmitted infections (STIs) and related topics 
(SIECUS, 2004). Sexuality Education is needed to help people gain insight into their sexuality, explore personal sexual issues and become more comfortable with their sexuality, dispel anxieties and doubts, resolve traumatic sexual experiences, learn how to avoid risky sexual behaviour.

Knowledge on human sexual behaviour is integral part of sexuality education which is important in addressing risky sexual behaviour (Khan, Townsend \& D'Costa, 2002). Most conflicts, sexually infections and unplanned pregnancies in marriages are as a result of risky sexual behaviour (Kelly, 2005). Inadequate programmes, lack of appropriated knowledge on sexual behaviour leave the youth at the mercy of the media and misinformation from peers. Parents, teachers and health professionals are often unable to communicate effectively with young people about their sexuality and sexual behaviour. Tanton et al reports that many young women have lower level of power or control in their sexual relationships. On the other hand young men may feel the pressure from their peers to act according to male sexual stereotypes and engage in controlling harmful behaviours. Good quality sexuality education has an impact on positive attitudes and values and can even out the power dynamics in intimate relationships contributing to prevention of abuse and fostering mutually respectful consensual partnerships (European Expert Group on Sexuality Education, 2016).

According to Kyalo (2012), human sexuality was highly valued in Tradition African Societies. Sexuality and sexual development carried special religious and mythic significance in African Communities (Mbiti, 1987). In traditional African communities, there are laid down rules guiding sexual behaviour, which were both universal and relative in view of cultural diversity (Famulusi, 2007). These rules guiding sexual behavior were taught from childhood and emphasized at initiation.. Among the Tanzanian Communities, every initiate whether a boy or a girl was given a guide the guide at initiation was known as Somo who instructed them on sexuality related issues (Fuglesang, 1997). Just like within the Tanzanian communities, among the Ameru, every initiate given a guide who instructed them on sexuality related issues and this guide was known as "Mugwati". Sexuality among the Meru had a goal of ensuring that there were stable and functional marriages.

Records from the courts in Meru County in 2016 indicated that there was an increase in divorces cases filed in the county. Some of the reasons of the divorces in Meru County include: couples being afraid to discuss with each other various issues affecting their marital relationships majorly sexual issues and annoying habits which were repeatedly blown out of proportion. Many couples also indicated that there was physical, emotional and/or social abuse in the marriages. This study hypothesized that the change in sources of knowledge on sexual behaviour might be the cause of change in satisfaction and stability in marriages in Meru County. The study thus sought to establish the association between sources of knowledge on sexual behaviour and marital satisfaction.

\subsection{Research Design}

This study adopted a causal-comparative research design. Causal-comparative research

\subsection{Location of the Study}

The study was conducted in Meru County. Meru County is the home of the Ameru. There are 5 sub-ethnic groups of Meru living in Meru County namely, the Igoji, the Miutine, the Imenti, the Tigania and the Igembe.

The Ameru have eight cyclical age groups which are determined by the period a man is circumcised. The age groups include: Michubu, Ratanya, Lubetaa, Miriti, Guantai, Gichunge, Kiramunya and Ithalii. Within the each age group, there are three age sets beginning with Ndinguri, followed by Kobia then finally Kaberia. Meru women adopt their husband age groups (Nyaga, 1997).

The age groups in existence at the time of this study included:

\begin{tabular}{|l|l|}
\hline Age Group & Period of Circumcision \\
\hline Michubu & 1933 to 1948 \\
\hline Ratanya & 1949 to 1959 \\
\hline Lubetaa & 1960 to 1970 \\
\hline Miriti & 1970 to 1984 \\
\hline Guantai & 1985 to 1997 \\
\hline Gichunge & 1998 to 2012 \\
\hline Kiramunya & 2013 to when the next age group is named \\
\hline
\end{tabular}




\subsection{Population of the Study}

The target population was 474,263married people in Meru County as at the 2009 population census (Kenya National Bureau of Statistics, 2017). These married people are distributed into various age groups.

1.6 Sampling Procedures and Sample Size.

A sample of 384 subjects was used in the study.. The sample was then divided by six to represent the number of age groups hence there were 64 respondents from each age group.

\subsection{Research Instruments}

A set of questionnaires, interview schedules and focus group discussions (FDGs) were used to collect information for the study.

\subsection{Ethical Considerations}

This study was guided by the ethical principles of psychological code of conduct in conducting research as indicated in the American Psychological Association (APA, 2002).

\subsection{Results}

The findings of the study are discussed below

\subsection{Sex of the Respondents}

Out of the 43 respondents who participated in the FDGs, $46.5 \%$ were male while $53.4 \%$ were female. $50 \%$ of male and female respondents were interviewed. There were $48.6 \%$ were male respondents and $51.4 \%$ female respondents to the questionnaires.

\subsection{Age Group of the Respondents}

Majority of the male $(21.7 \%)$ and female $(21.8 \%)$ respondents were from the Gichunge and Guantai age group. The least number of the male $(16.8 \%)$ and female $(15.9 \%)$ respondents were from the Ratanya age group, (Table 3)

Table 1

Percentages of respondents with respect to age group

\begin{tabular}{lcc}
\hline \hline Age group & Male & Female \\
\hline Ratanya & 16.8 & 15.9 \\
Lubetaa & 18.9 & 19.9 \\
Mung'atia & 21.0 & 20.5 \\
Mburung'a & 21.7 & 21.9 \\
Gichunge & 21.7 & 21.9 \\
Total & 100.0 & 100.0 \\
\hline
\end{tabular}

\subsection{Level of Formal Education of the Respondents}

Majority of the male (32.9\%) and female (34.4\%) respondents had attained secondary level of Education (Table 4)

Table 2

Percentage of respondent with respect to formal education

\begin{tabular}{lll}
\hline Level of Formal Education & Male & Female \\
\hline None & 1.4 & 6.0 \\
Primary & 27.3 & 31.1 \\
Secondary & 32.9 & 34.4 \\
Diploma & 18.9 & 15.2 \\
Bachelors Degree & 11.2 & 11.3 \\
Postgraduate & 8.4 & 2.0 \\
Total & 100.0 & 100.0 \\
\hline
\end{tabular}

\subsection{Religious Affiliation of the Respondents}

Most of the male respondents $(53.1 \%)$ were Catholics while the most of the female respondents $(57.6 \%)$ were also Catholics (Table 5). 
Table 3

Percentage of respondent with respect to religious affiliation

\begin{tabular}{lcc}
\hline \hline Religious affiliation & Male & Female \\
\hline None & 3.5 & 2.0 \\
Protestant & 39.9 & 38.4 \\
Catholic & 53.1 & 57.6 \\
Muslim & 2.1 & 2.0 \\
Other & 1.4 & 100.0 \\
Total & 100.0 & \\
\hline
\end{tabular}

\subsection{Rite of Initiation of the respondents}

Most the male respondents $(75.5 \%)$ and most of the female respondents $(45.0 \%)$ had undergone the traditional rite of initiation (Table 6)

Table 4

Percentage of respondent with respect to rite of initiation

\begin{tabular}{lcc}
\hline Rite of initiation & Male & Female \\
\hline Traditional & 75.5 & 45.0 \\
Modern & 25.5 & 11.9 \\
None & 0.0 & 43.1 \\
Total & 45.0 & 100.0 \\
\hline
\end{tabular}

2.6 Period in Marriage of the respondents

Majority of the male respondents $(32.2 \%)$ and majority of the female respondents $(27.8 \%)$ had been married for more than 20 years (Table 5)

Table 5

Period in Marriage of the Respondents in percentage

\begin{tabular}{lcc}
\hline Duration in marriage & Male & Female \\
\hline 1-5 Years & 29.4 & 17.2 \\
6-10 Years & 18.2 & 23.8 \\
11-15 Years & 7.0 & 17.2 \\
16-20 Years & 13.3 & 13.9 \\
Over 20 Years & 32.2 & 27.8 \\
Total & 100.0 & 100.0 \\
\hline
\end{tabular}

2.6 Sources

of Knowledge on Sexual Behaviour among Married People in Meru County

The study explored sources of knowledge on sexuality throughout life, shared sexual behaviour, abstinence, sexual response cycle and sexual dysfunction as the areas of sexual behaviour (Table 6)

These findings reveal that peers, sponsors at initiation, none, spouses, books and magazines were the top five most influential sources of knowledge on human sexual behaviour among married people in Meru County.

2.7 Comparison of Sources of Knowledge on Sexual Behaviour among Married People in Meru County Comparison on sources of knowledge on sexual behaviour was done based on sex, age group, Level of Formal Education, rite of passage and length of stay in marriage. Independent t-test and ANOVAs were done to compare the differences.

\subsubsection{Comparison of Sources of Knowledge on Sexual Behaviour based on Sex}

An independent samples t-test was used to compare sources of knowledge on sexual behaviour between males and females. Findings did not give evidence to conclude that there were statistically significant differences in sources of knowledge on sexual behaviour between male and female respondents $(t=0.182, p=0.670)$.

\subsubsection{Comparison of Sources of Knowledge on Sexual Behaviour Based on Age Group}

ANOVA was used to compare the sources of knowledge on sexual behaviour based on age group. Results did not provide strong evidence to conclude that there was a statistically significant difference in sources of knowledge on sexual behaviour among married people in Meru County based on their age groups $(F=2.339 . p=0.055)$ 
2.7.3 Comparison of Sources of Knowledge on Sexual Behaviour Based on Level of Formal Education

ANOVA was done to compare sources of knowledge on sexual behaviour based on level of formal education. Findings provide a strong evidence to conclude that there were statistically significant differences in sources of knowledge on sexual behaviour among married people in Meru County based on their level of formal education $(F=6.594, p<0.001$ Post hoc tests were done to establish the groups that were different. Findings are presented in Table 9

Table 6

Sources of Knowledge on Human Sexual Behavior

\begin{tabular}{|c|c|c|c|c|c|c|c|c|c|c|}
\hline \multirow[b]{2}{*}{ Source } & \multirow{2}{*}{$\begin{array}{l}\text { Knowledge } \\
\text { Sexuality } \\
\text { Life } \\
\text { Male (\%) }\end{array}$} & \multirow{2}{*}{$\begin{array}{l}\text { on } \\
\text { Throughout } \\
\text { Female } \\
(\%)\end{array}$} & \multicolumn{2}{|c|}{$\begin{array}{l}\text { Knowledge on Shared } \\
\text { Sexual Behaviour, }\end{array}$} & \multicolumn{2}{|c|}{$\begin{array}{l}\text { Knowledge } \\
\text { Abstinence, }\end{array}$} & \multicolumn{2}{|c|}{$\begin{array}{l}\text { Knowledge on Sexual } \\
\text { Response Cycle }\end{array}$} & \multicolumn{2}{|c|}{$\begin{array}{l}\text { Knowledge on Sexual } \\
\text { Dysfunction }\end{array}$} \\
\hline & & & $\begin{array}{l}\text { Male } \\
(\%)\end{array}$ & $\begin{array}{l}\text { Female } \\
(\%)\end{array}$ & $\begin{array}{l}\text { Male } \\
(\%)\end{array}$ & $\begin{array}{l}\text { Female } \\
(\%)\end{array}$ & $\begin{array}{l}\text { Male } \\
(\%)\end{array}$ & $\begin{array}{l}\text { Female } \\
(\%)\end{array}$ & $\begin{array}{l}\text { Male } \\
(\%)\end{array}$ & $\begin{array}{l}\text { Female } \\
(\%)\end{array}$ \\
\hline $\begin{array}{l}\text { School } \\
\text { Teachers }\end{array}$ & 1.4 & 2.6 & 6.6 & 11.3 & 7.7 & 6.0 & 14.7 & 11.3 & 12.6 & 8.6 \\
\hline Parents & 2.8 & 3.3 & 9.8 & 4.2 & 4.9 & 10.6 & 3.5 & 1.3 & 3.5 & 3.3 \\
\hline Grandparents & 3.5 & 8.6 & 1.4 & 2.6 & 4.2 & 5.3 & 0.7 & 3.5 & - & 4.0 \\
\hline $\begin{array}{l}\text { Aunts and } \\
\text { Uncles }\end{array}$ & 3.5 & 2.0 & 2.8 & 6.0 & 4.9 & 9.9 & & 5.6 & 0.7 & 4.6 \\
\hline Peers & 28.0 & 23.8 & 40.2 & 31.9 & 4.9 & 1.3 & 11.2 & 12.6 & 13.3 & 7.3 \\
\hline $\begin{array}{l}\text { Religious } \\
\text { Leaders }\end{array}$ & 2.1 & 2.0 & 1.4 & 4.1 & 4.9 & 7.9 & 7.0 & 4.2 & 3.5 & 1.3 \\
\hline $\begin{array}{l}\text { Sponsors at } \\
\text { Initiation }\end{array}$ & 25.2 & 15.2 & 1.4 & 10.6 & 18.9 & 9.3 & 21.7 & 7.9 & 12.6 & 5.3 \\
\hline Spouses & 4.9 & 7.4 & 16.1 & 20.5 & 3.5 & 21.2 & 4.9 & 3.0 & 10.5 & 16.6 \\
\hline Professionals & 7.0 & 2.0 & 11.9 & 1.3 & 1.4 & 12.6 & 7.0 & 5.3 & 10.5 & 11.9 \\
\hline Radio & 1.3 & 1.3 & & 2.2 & 0.7 & 4.0 & 4.1 & 1.3 & 1.4 & 2.0 \\
\hline Television & & & & & & & 4.2 & 5.6 & 4.2 & - \\
\hline Internet & 2.1 & 4.6 & & & & & 2.1 & 4.0 & 1.4 & 2.0 \\
\hline $\begin{array}{l}\text { Books and } \\
\text { Magazines }\end{array}$ & 11.9 & 12.6 & 5.6 & 4.0 & 19.6 & 11.9 & 9.1 & 11.9 & 11.2 & 9.9 \\
\hline None & 6.3 & 14.6 & & 1.3 & 24.4 & & 7.7 & 17.9 & 14.6 & 23.2 \\
\hline Others & & & 2.8 & & & & 2.1 & 4.6 & - & \\
\hline Total & 100.0 & 100.0 & 100.0 & 100.0 & 100.0 & 100.0 & 100.0 & 100.0 & 100.0 & 100.0 \\
\hline
\end{tabular}

2.7.4 Comparison of Sources of Knowledge on Sexual Behaviour Based on Religious Affiliations ANOVA was done to compare sources of knowledge on sexual behaviour based on religious affiliation. Results did not provide sufficient evidence to conclude that there were statistically

2.7.5 Comparison of Sources of Knowledge on Sexual Behavior Based on Rite of Initiation

ANOVA was carried out to compare sources of knowledge on sexual behaviour based on rite of passage. Findings did not provided evidence to conclude that there were statistically significant differences in sources of knowledge on sexual behaviour based on the rite of initiation $(F=0.590, p=0.555)$

\subsubsection{Comparison of Sources of Knowledge on Sexual Behaviour Based on Length in Marriage}

ANOVA was carried out to compare sources of knowledge on sexual behaviour based on length of stay in marriage. Results did not provide evidence to conclude that there were statistically significant differences in sources of knowledge on sexual behaviour based on length in marriage $(F=0.286, p=0.887)$

\subsection{Association between Sources of Knowledge on Sexual Behaviour and Marital Satisfaction} Spearman rank correlation was done to determine the relationship between sources of knowledge on sexual behaviour and marital satisfaction, Table 13 
Table 9

Multiple Comparisons of Sources of Knowledge on Sexual Behaviour Based on Level of Formal Education

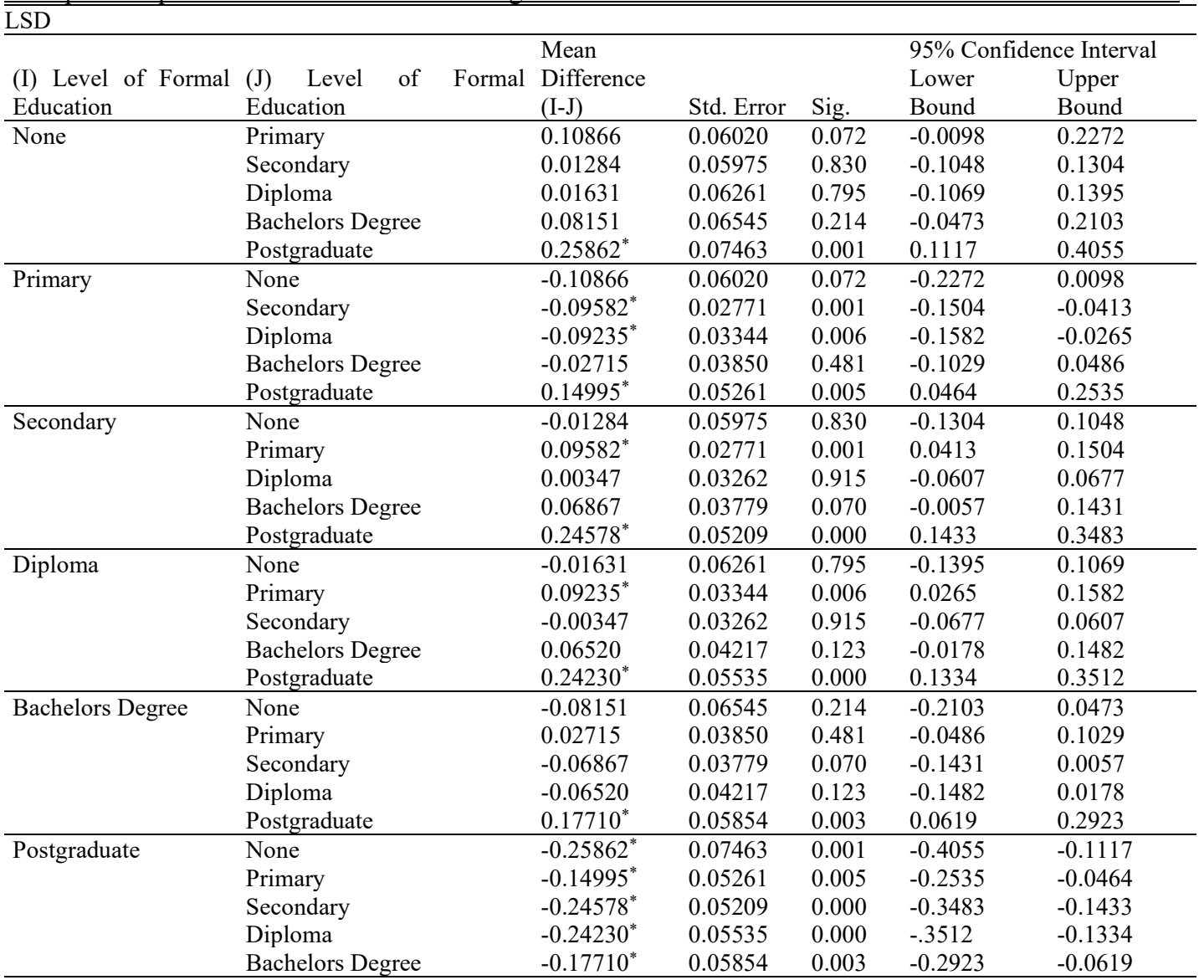

*. The mean difference is significant at the 0.05 level.

Table 4:

Relationship between Sources of Knowledge on Sexual Behaviour and Marital Satisfaction among Married People in Meru County

\begin{tabular}{|c|c|c|c|c|c|c|}
\hline & & & Intimacy & Commitment & Passion & $\begin{array}{c}\text { Marital } \\
\text { Satisfaction }\end{array}$ \\
\hline \multirow{15}{*}{$\begin{array}{l}\text { Spearman's } \\
\text { rho }\end{array}$} & \multirow{3}{*}{$\begin{array}{l}\text { Sources of Knowledge on Changes in Sexuality } \\
\text { Throughout Life }\end{array}$} & $\begin{array}{l}\text { Correlation } \\
\text { Coefficient }\end{array}$ & $.148^{*}$ & .016 & -.041 & .045 \\
\hline & & Sig. (2-tailed) & .011 & .790 & .487 & .442 \\
\hline & & $\mathrm{N}$ & 294 & 292 & 294 & 292 \\
\hline & \multirow[t]{3}{*}{ Sources of Knowledge on Abstinence } & $\begin{array}{l}\text { Correlation } \\
\text { Coefficient }\end{array}$ & $.159^{* *}$ & .052 & $.145^{*}$ & $.143^{*}$ \\
\hline & & Sig. (2-tailed) & .006 & .374 & .013 & .014 \\
\hline & & $\mathrm{N}$ & 294 & 292 & 294 & 292 \\
\hline & \multirow[t]{3}{*}{$\begin{array}{l}\text { Sources of Knowledge on Sexual Response } \\
\text { Cycle }\end{array}$} & $\begin{array}{l}\text { Correlation } \\
\text { Coefficient }\end{array}$ & .087 & -.003 & .072 & .059 \\
\hline & & Sig. (2-tailed) & .139 & .964 & .219 & .318 \\
\hline & & $\mathrm{N}$ & 294 & 292 & 294 & 292 \\
\hline & \multirow[t]{3}{*}{ Sources of Knowledge on Sexual Dsyfunctions } & $\begin{array}{l}\text { Correlation } \\
\text { Coefficient }\end{array}$ & -.009 & $-.259^{* *}$ & -.085 & $-.154^{* *}$ \\
\hline & & Sig. (2-tailed) & .879 & .000 & .145 & .008 \\
\hline & & $\mathrm{N}$ & 294 & 292 & 294 & 292 \\
\hline & \multirow[t]{3}{*}{ Sources of Education on Sexual Behaviour } & $\begin{array}{l}\text { Correlation } \\
\text { Coefficient }\end{array}$ & $.181^{* *}$ & -.020 & .010 & .050 \\
\hline & & Sig. (2-tailed) & .002 & .735 & .869 & .393 \\
\hline & & $\mathrm{N}$ & 294 & 292 & 294 & 292 \\
\hline
\end{tabular}

**. Correlation is significant at the 0.01 level (2-tailed)

*. Correlation is significant at the 0.05 level (2-tailed). 
Results in Table 13 gives evidence of a very weak positive association that was significant was detected when sources of knowledge on sexuality throughout life were correlated with intimacy $\left(r_{s}=0.148, p=0.011\right)$. There was also evidence of a very weak positive relationship that was not significant when sources of knowledge on sexuality throughout life were correlated with commitment $\left(r_{s}=0.016, p=0.760\right)$ and marital satisfaction $\left(r_{s}=0.045, p=0.442\right)$.

Evidence of a weak positive association that was significant was provided when sources of knowledge on abstinence was correlated with intimacy $\left(r_{s}=0.159, p=0.006\right)$, passion $\left(r_{s}=0.145, p=0.013\right)$ and marital satisfaction $\left(r_{s}=0.143, p=0.014\right)$. A very weak positive association that was not significant was noted when sources of knowledge on abstince was compared with commitment $\left(r_{s}=-0.052, p=0.374\right)$.

There was evidence of a weak positive association that was not significant when sources of knowledge on sexual response cycle were correlated with intimacy $\left(r_{s}=0.087, p=0.139\right)$, passion $\left(r_{s}=0.792, p=0.219\right)$ and marital satisfaction $\left(r_{s}=0.059, p=0.318\right)$. A very weak negative association that was also not significant was observed when sources of knowledge on sexual response cycle were compared correlated with commitment $\left(r_{s}=-0.003\right.$, $p=0.964$ )

A very weak negative association that was not significant was noted when sources of knowledge on sexual dysfunctions were correlated with intimacy $\left(r_{s}=-0.009, p=0.876\right)$ and passion $\left(r_{s}=-0.259, p=0.145\right)$. A weak negative association was observed when sources of knowledge on sexual dsyfunctions were correlated with commitment $\left(r_{s}=-0.259, p<0.001\right)$. A weak positive association that was significant were observed when sources of knowledge on sexual dysfunctions were correlated with marital satisfaction $\left(r_{s}=0.050, p=0.393\right)$.

A weak positive association that was significant was proved when sources of knowledge on sexual behaviour were correlated with intimacy $\left(r_{s}=0.181 . p=0.002\right)$. There was also evidence of a weak negative correlation which was not significant when sources of knowledge on sexual behaviour were correlated with passion $\left(r_{s}=-0.020, p=0.735\right)$. A weak positive correlation which was not significant was demonstrated when sources of knowledge on sexual behaviour wre correlated with passion $\left(r_{s}=0.010, p=0.869\right)$ and marital satisfaction $\left(r_{s}=0.050, p=0.393\right)$.

\section{Discussion}

Most of the married did not have an influential source of knowledge on sexual behavior. These findings agree with the results of the FDGs where most respondents indicated that they learnt about sexual behavior through experience. The findings also agreed with the reports from FDGs that Meru People did not pay serious attention in teaching young people about abstinence. The findings also raised concerns of the campaigns against spread HIV/AIDs that recommends abstinence as the first option to stop the spread of HIV yet most people have no influential source of abstinence. This can help explain the rampant infidelity in marriages as reported by population council (2007) who established that a high number of young married people engaging in infidelity.

Married men indicated that their most influential source of knowledge on sexual response cycle from sponsors at initiation while most married women indicated that they had no most influential source of knowledge on sexual response. Understanding sexual response cycle is important in sexual satisfaction in marriage. Therefore where women have no clear knowledge on sexual response cycle and men have some understanding of sexual response cycle, there is likely to conflicts that lead to sexual dissatisfaction in marriage.

Both married men and women also reported that they had no most influential source of knowledge on sexual dysfunctions. Understanding of sexual response cycle and sexual dysfunctions is very important for sexual fulfillment in marriages. It is also influential in helping partners assist one another during the periods of sexual difficulties. It is therefore necessary for stake holders in education to revisit the issues of introducing sex education in schools to teach sexual behavior with a focus of enhancing marital satifaction. This is because there is no influential source of many aspects of sexual behavior.

\section{Conclusion}

There was a wide variety of sources of knowledge on human sexual behaviour. Level of formal education was significant in explaining differences in sources of knowledge on human sexual behaviour. There was a significant association between sources of knowledge on human sexual behaviour and marital satisfaction therefore it is necessary to standardize the sources. 


\section{Recommendation}

It is necessary to incorporated Knowledge on human sexual behavior that is tailored in improving marital satisfaction in the formal school curriculum in Kenya. So the ministry of education, ministry of health and ministry of culture need to work with the Kenya institute of curriculum development to develop an appropriate curriculum.

\section{References}

Bradbury, T. N., Fincham, F. D., \& Beach, S. R. H. (2000). Re-search on the nature and determinants of marital satisfaction: A decade in review. Journal of Marriage and the Family, 62 (4), 964-980.

European Expert Group on Sexuality Education (2016) Sexuality education - what is it?, Sex Education, 16:4,427-431, DOI: 10.1080/14681811.2015.1100599

Familusi, O.O. (2017). Human Sexuality in African Thought and the HIV/AIDS Scourge . Lamina (22), 11882094

Gordon, P. (2007). Review of Sex, Relationships and HIV Education in Schools Prepared for the first meeting of UNESCO's Global Advisory Group meeting 13-14 December 2007. Paris: UNESCO. (Availableathttp://unesdoc.unesco.org/images/0016/001629/162989e.pdf)

Kelly, F. G (2005). Re-Visioning Sexuality Education: A challenge for future. American Journal of Sexuality Education Vol 1. Available Online at http//www.haworthpress.com/web/AJSE.

Khan, M. E., Townsend, J.W, \& D'Costa, S. (2002) Behind closed doors: A qualitative study of sexual behaviour of married women in Bangladesh, Culture, Health \& Sexuality, 4:2, 237256, DOI: $\underline{10.1080 / 13691050110102253}$

Kyalo P., (2012). A reflection on the African Traditional Values of Marriage and Sexuality. In International Journal of Academic Research in Progressive Education and Development. Vol. 1. No. 2. SSN: 22266348211

Mbiti, S.J. (1987). African Religious Philosophy. New York. Anchor Books

Sexuality Information and Education Council of the United State (SEICUS). (2004). Guidelines for Comprehensive Sexuality Education, Kindergarten through $12^{\text {th }}$ Grade. National Task Force $3^{\text {rd }}$ Ed. Washington DC: SEICUS

Population council. (2007). Adolescence in Kibera Slums Nairobi, Population Council, USA,

Tanton, C., K., G. Jones, W. Macdowell, S. Clifton, K.R. Mitchell, J. Datta, R. Lewis et al. (2015). "Patterns and Trends in Sources of Information about Sex among Young People in Britain: Evidence from Three National Surveys of Sexual Attitudes and Lifestyles.” BMJOpen 5: e007834.http://bmjopen.bmj.com/content/5/3/e007834.full [Google Scholar] 